\title{
Biosynthesis of zinc oxide nanoparticles by using fruits extracts of Ananas comosus and its antibacterial activity
}

\author{
Raja Adibah Raja Ahmad a, b , Zawati Harun ${ }^{\text {a, b, }}{ }^{\star}$, Mohd Hafiz Dzarfan Othman ${ }^{\text {c }}$, Hatijah Basri ${ }^{d}$, \\ Muhamad Zaini Yunos ${ }^{\text {a, b }}$, Azlinnorazia Ahmad ${ }^{\text {a, b }}$, Siti Hajar Mohd Akhair ${ }^{\text {a, b }}$, Abdul Qaiyyum Abd \\ Rashid $^{\text {a, b }}$, Faiz Hafeez Azhar ${ }^{\text {a, b }}$, Siti Salwa Alias ${ }^{\text {a }}$, Ainun Rahmahwati Ainuddin ${ }^{\text {b }}$ \\ a Integrated Materials and Process(IMP), Advanced Materials and Manufacturing Centre (AMMC), Faculty of Mechanical and Manufacturing \\ Engineering, Universiti Tun Hussein Onn Malaysia, 86400 Parit Raja, Batu Pahat, Johor Darul Takzim, Malaysia \\ ${ }^{b}$ Faculty of Mechanical and Manufacturing Engineering, Universiti Tun Hussein Onn Malaysia, Parit Raja, 86400 Batu Pahat, Johor, Malaysia \\ ' Advance Membrane Technology Research Centre (AMTEC), Faculty of Chemical and Energy Engineering, Universiti Teknologi Malaysia (UTM), \\ 81310 Skudai, Johor, Malaysia \\ ${ }^{d}$ Faculty of Applied Sciences and Technology, Universiti Tun Hussein Onn Malaysia, Pagoh Campus, 84600 Panchor, Muar, Johor, Malaysia \\ * Corresponding author: zawati@uthm.edu.my
}

Article history

Received 5 May 2018

Revised 1 June 2018

Accepted 2 July 2018

Published Online 14 April 2019

\begin{abstract}
Biosynthesis of metallic nanoparticles using plants, enzymes, and microorganism has been known as eco-friendly alternative compared to other conventional physical and chemical methods. Recently, the biological synthesis of nanoparticles has been a keen interest among researchers and scientists due to its simple technique, eco-friendliness, non-toxic and low in cost. Thus, in this current work, the synthesis of zinc oxide nanoparticles (ZnO-NPs) using reduction agent from fruit extracts of Ananas Comosus was reported. The biosynthesized ZnO-NPs were characterized using Field Emission Scanning Electron Microscope (FESEM) paired with Energy Dispersive X-ray analysis (EDX), UV-Vis absorption spectroscopy and X-ray diffraction (XRD). The average size of the nanoparticles was found to be in the range of 30-57nm. The antibacterial activity of ZnO-NPs was performed via agar diffusion method against pathogenic organisms. It was observed that the biosynthesized ZnO-NPs in the process has the efficient antibacterial performance against Escherichia coli (E-coli). In conclusion, the green synthesized ZnO-NPs using the fruit extract of Ananas Comosus was successfully conducted and interestingly it has also been proved to exhibit antibacterial effect against E. coli strains.
\end{abstract}

Keywords: Green synthesized $\mathrm{ZnO}$, Ananas comosus, fruit extract, nanoparticles, antibacterial activity

(ㄷ) 2019 Penerbit UTM Press. All rights reserved

\section{INTRODUCTION}

Researchers nowdays have keen interest towards zinc oxides $(\mathrm{ZnO})$ especially in nanostructure scales due to their wide applications and unique properties. The widely use of $\mathrm{ZnO}$ and tremendous interest recently, especially in the semiconductor and photocatalytic appplication, are resulted from a direct wide gap $(3.37 \mathrm{eV}, 387 \mathrm{~nm})$, deep violet/borderline ultraviolet (UV) and a large exciton-binding energy $(60 \mathrm{meV})$ (B. Kumar et al. 2014). $\mathrm{ZnO}$ is a highly preferred material as it ables to act as multitasking metal oxide, with a vast list of attractive properties for various applications. Due to its exceptional optical and electrical properties (Könenkamp et al. 2002), it is regarded as a potential material to be used in optoelectronic applications which is effective in the visible and near ultraviolet spectral regions. Zinc oxide nanoparticles (ZnO-NPs) are widely used in many industrial areas such as solar cells (R. Vittala 2017), UV light-emitting devices (Y.-J. Lu et al. 2017), gas sensors (Galstyan et al. 2015), photocatalysts (Chen et al. 2017), pharmaceutical (KarimiMaleh et al. 2014) and cosmetic industries (P. J. Lu et al. 2015).

Recently, $\mathrm{ZnO}$ has turned out to be one of the most crucial and multifunctional semiconductor materials which extensively applied as photo-catalyst and antibacterial materials. Balta et al. (2012) in their study reported that the utilization of $\mathrm{ZnO}-\mathrm{NPs}$ did not create and increase toxicity level since the surface area and size distribution of the particles were too small, making the effect was too far from toxicity level. (Balta et al. 2012).

In fact, ZnO-NPs are safer and less toxic compared with other metal oxide nanoparticles, therefore it has been increasingly used in applications such as food industries for processing and packaging of vegetables and meats (Raj and Jayalakshmy 2015). There are various methods that have recently been used for the synthesis of $\mathrm{ZnO}-\mathrm{NPs}$, such as sol gel method, direct precipitation, thermal decomposition, sonochemical method, microwave irradiation, solvothermal method, reverse micelles, hydrothermal and homogeneous precipitation (Arora et al. 2014). However, the application of chemical and physical methods in production of ZnO-NPs is yet costly and hazardous.

Recently, there is growing need to environmental friendly nanoparticles synthesis method known as biological synthesis, where the process of synthesizing nanoparticles by using plants, enzymes, alga and microorganisms have been proposed. This approach offers an eco-friendly alternative in synthesizing route compared to the physical and chemical methods, along with better effect and 
performance (Azizi, Ahmad, and Mohamad 2013). As for example, the ZnO-NPs were succesfully synthesized by using plants of Lycopersicon esculentum extract (Sutradhar and Saha 2017), Allium sativum, Rosmarinus officinalis and Ocimum basilicum extracts (Stan et al. 2016), Trifolium pratense flower extract (Dobrucka and Długaszewska 2015) and Root Extract of Zingiber officinale (Raj and Jayalakshmy 2015). Futher investigation on this approach also was conducted by Zheng et al. (2015) and Azizi et al. (2014), that reported on the synthesis of ZnO-NPs using Corymbia citriodora leaf extract and marine macroalga Sargassum muticum aqueous.

Utilization of ZnO-NPs is beneficial due to their ability to inhibit the growth of pathogenic microbes in minute concentration (Applerot et al., 2009). Based on the previous study, it was reported that $\mathrm{ZnO}$ exhibited significant growth in inhibition of a broad spectrum of bacteria. The antibacterial activity of $\mathrm{ZnO}-\mathrm{NPs}$ was reported against clinical isolates: Escherichia coli, Bacillus subtilis, Salmonella typhi, Klebsiella pneumoniae, Staphylococcus aureus, and Pseudomonas aeruginosa (Jeeva et al., 2012). In the previous work, Prasad and Krishna (2016) attempted to synthesize ZnO-NPs using the Boswellia ovalifoliolata stem bark extract. The results showed that ZnO-NPs exhibited good antibacterial activity against Gram positive bacteria and Gram negative bacteria.

In this study, pineapple (Ananas comosus) was used as the reduction agent to synthesize the ZnO-NPs. Ananas Comosus is a tropical plant which broadly cultivated for its unique feature of yellow flesh and sweet juice. Now, pineapple is the world's third most essential cultivated tropical fruit after bananas and citrus. The suitable place for pineapple to grow is in frost-free areas around the world. Nutritionally, pineapple is an excellent source of vitamins C, A and also potassium. Recent studies proved that vitamin $\mathrm{C}$ presented in plants has potential to be used for the synthesis of zinc oxide and silver nanoparticles (Sutradhar and Saha 2017, Shrikant R. et. al. 2011).

Therefore, the aim of this current study was to investigate the properties of Ananas comosus as the reduction agent for the biosynthesis of ZnO-NPs. Further investigation on the effect of antibacterial properties of the biosynthesis $\mathrm{ZnO}-\mathrm{NPs}$ was also carried out.

\section{EXPERIMENTAL}

\section{Materials}

The Ananas Comosus (pineapple) fruits were collected from the local source in Parit Raja, Johor, Malaysia. Zinc nitrate was purchased from Sigma Aldrich and distilled water was used throughout the experiments.

Bacterial strains used for the antibacterial test of $\mathrm{ZnO}$ nanoparticles was Escherichia coli (E. coli) ATCC 25922.

\section{Preparation of pineapple fruit extract}

The fresh Ananas Comosus (pineapple) fruits were collected from the local market and the skin was cut thoroughly. Then, it was washed with double distilled water and cut into small pieces subsequently. After that, the small pieces of pineapple were squeezed to get the juice. The juice was then dissolved in distilled water with stirring time of 10 minutes at $40^{\circ} \mathrm{C}$ and filtered using a Whatman filter paper (Sutradhar and Saha 2017). The filtrate was collected and kept below $10^{\circ} \mathrm{C}$ for further use. A step flow chart of the juice preparation was as in Fig. 1.

\section{Bio-synthesis of ZnO-NPs}

The precursor for the $\mathrm{ZnO}-\mathrm{NPs}$ in this synthesis was zinc nitrate. The zinc nitrate and pineapple extract were mixed in the ratio of $1: 3$ and stirred at $240^{\circ} \mathrm{C}$ for 5 minutes until brownish-black precipitation was produced. The solution was then centrifudged at 10000rpm for 7 minutes. The precipitates were collected and then dried in oven at 40$100^{\circ} \mathrm{C}$. All the precipitates were collected in glass container to be further characterized.

\section{Preparation of pineapple fruit extract :}

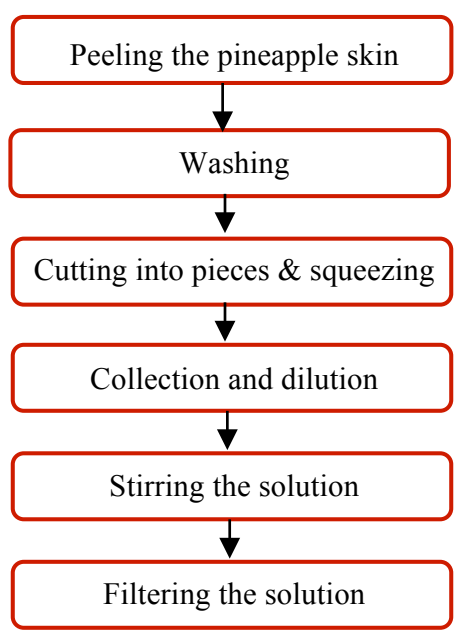

Fig.1. Preparation of pineapple fruit extract.

\section{Characterization of $\mathrm{ZnO}-\mathrm{NPs}$}

\section{X-ray diffraction (XRD)}

The X-ray diffraction (XRD) measurement of biosynthesized ZnO-NPs was carried out using an X-ray diffractometer with $\mathrm{Cu} \mathrm{K}_{\alpha}$ radiation $(\lambda=0.154 \mathrm{~nm}, \mathrm{D} /$ max-rB $12 \mathrm{~kW}$ Rigaku) which operated at $30 \mathrm{~mA}$ and $40 \mathrm{kV}$ from $10^{\circ}$ and $80^{\circ}$ with a step increment rate of $0.05^{\circ} / \mathrm{min}$. The estimation of the particle size was performed by using Scherrer's formula (1).

The Scherrer's formula could be used to calculate the crystalline size of particle

$$
D=\mathrm{K} \lambda / \beta \cos \theta
$$

where,

$$
\begin{aligned}
& D \text { is the crystalline size of the particles, } \\
& \lambda^{\lambda} \text { is the wavelength of the X-ray used, } \\
& \mathrm{K} \text { is the shape factor, } \\
& \beta^{\beta} \text { is the full line width at the half-maximum } \\
& \text { elevation of the main intensity peak, and } \\
& \theta \text { is the Bragg angle. }
\end{aligned}
$$

\section{Field emmision scanning electron microscope (FESEM)}

The shape and size of the synthesized $\mathrm{ZnO}$-NPs were examined by using Field emission scanning electron microscope (FESEM). The samples were placed on an adhesive carbon tape supported on copper stubs and coated with $10 \mathrm{~nm}$ thick gold using JEOL JFC-1600 auto fine coater before measurement (Karunakaran, Rajeswari, and Gomathisankar 2011).

\section{Energy dispersive X-ray diffraction (EDX)}

The energy dispersive X-ray diffraction (EDX) which attached with FESEM was used to obtain the elemental analysis with acceleration voltage of $15.0 \mathrm{kV}$ and working distance of $11.6 \mathrm{~mm}$ and $15.0 \mathrm{~mm}$ for FESEM and EDX, respectively. Copper tape was used as tape detector.

\section{UV-Vis Absorbance for ZnO-NPs}

As for UV-Vis spectra analysis, the maximum absorbance was measured by using UV-Vis Spectrophotometer Perkin Elmer model G10S UV-Vis with wavelength in the range of $280-800 \mathrm{~nm}$.

\section{Antibacterial activity of the biosynthesized $\mathrm{ZnO}$ nanoparticles}

The agar diffusion method was used to test the ZnO-NPs for their antibacterial activity against strains (Stan et al. 2016). The E. coli bacteria were grown in nutrient broth to prepare stock solutions of 100 $\mu \mathrm{g} / \mathrm{mL}$. Later, $100 \mu \mathrm{L}$ of bacteria inoculums was spreaded over the 
plates containing steriled nutrient agar. Paper filter disks $(6 \mathrm{~mm})$ were impregnated with $20 \mu \mathrm{L}$ of stock solution. The plates were maintained at room temperature for $30 \mathrm{~min}$ to allow the diffusion of the solutions. The inhibition zone around the disk was measured after incubation at $37^{\circ} \mathrm{C}$ for $24 \mathrm{~h}$ (Karunakaran, Rajeswari, and Gomathisankar 2011).

\section{RESULTS AND DISCUSSION}

\section{XRD patterns}

Fig. 2 shows the XRD pattern of the biosynthesized ZnO-NPs. The distinct diffraction peaks at $2 \theta=31.717^{\circ}, 34.484^{\circ}, 36.245^{\circ}$, $47.585^{\circ}, 56.705^{\circ}, 62.826^{\circ}, 66.580^{\circ}, 68.025^{\circ}$ and $69.039^{\circ}$ were assigned to (100), (002), (101), (102), (110), (103), (200), (112) and (201) planes, respectively. All the relative peaks of the biosynthesized $\mathrm{ZnO}-\mathrm{NPs}$ were matched with the Joint Committee on Powder Diffraction Standard (JCPDS) card number 00-065-0725 in terms of intensities and positions. All the peaks recorded in Fig. 2 were well indexed to the hexagonal phase of $\mathrm{ZnO}$ and the nanopowder was shown to be highly crystallized owing to the narrow and sharp peaks. The high intensity at the peak of (101) was as an indicative of anisotropic growth and thus, implying on a preferred orientation of the crystallites.

The crystallite size of the particles that calculated using this equation was found to be $12.2 \mathrm{~nm}$.

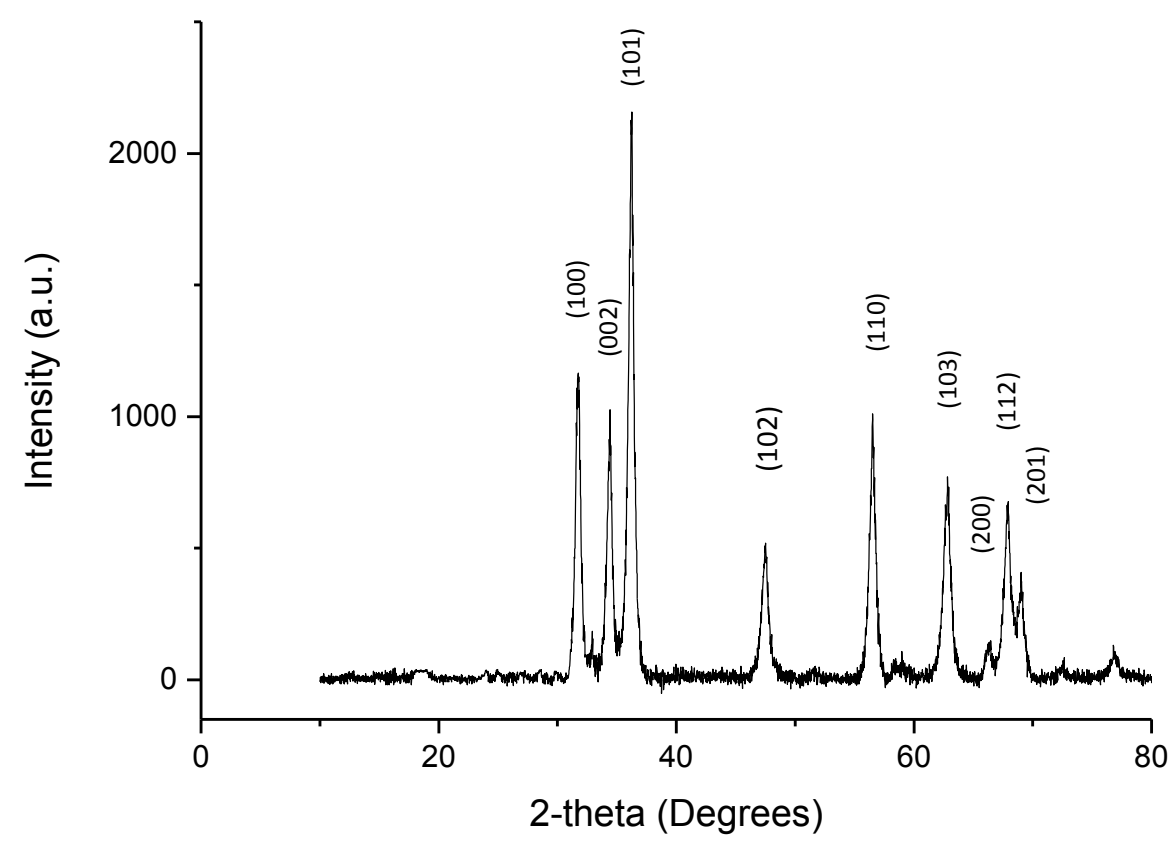

Fig.2. XRD pattern of biosynthesized $\mathrm{ZnO}$ nanoparticles.
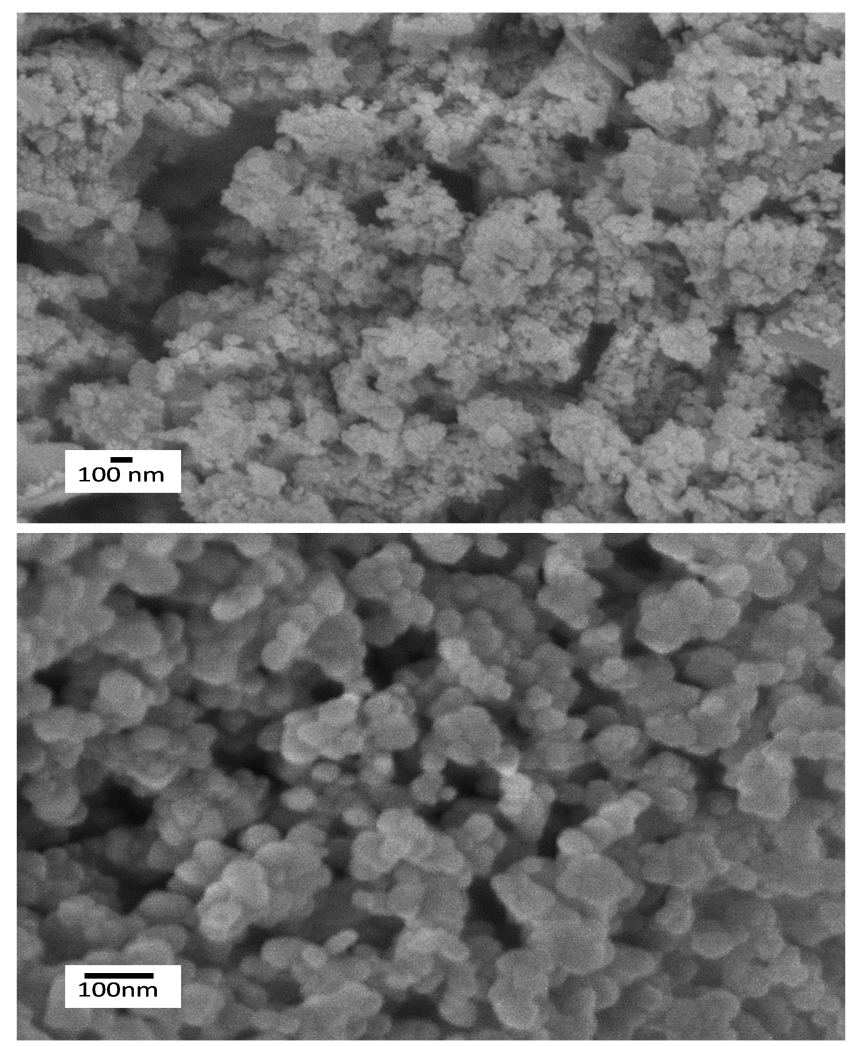

Fig. 3 FESEM images of ZnO-NPs.

\section{FESEM analysis}

FESEM images of biosynthesized ZnO-NPs were shown in Fig. 3. It could be observed from Fig. 3 that the synthesized nanoparticles formed were agglomerated with the hexagonal structures and the diameter size of the particles was ranged from 30 to $57 \mathrm{~nm}$. According to Raj and Jayalakshmy (2015), the particle size of the synthesized $\mathrm{ZnO}$ nanoparticles was in the range of $30-50 \mathrm{~nm}$ which was comparable to the results obtained in the present study. The spot numbered 1, 2, 3, 4 in the Fig. 3 was indicated for the points in which the measurement was made.

\section{EDX analysis}

The elemental analysis of the biosynthesized ZnO-NPs was carried out by using EDX to get further confirmation on the presence of $\mathrm{ZnO}-\mathrm{NPs}$ in the sample. The EDX spectrum of biosynthesized ZnO-NPs was shown in Fig. 4. The EDX result showed that the peaks were exhibited between $1 \mathrm{kV}$ and $6 \mathrm{kV}$. The peaks are were directly related to zinc and oxide that presented in the tested material. The results also presented that the biosynthesized $\mathrm{ZnO}-\mathrm{NPs}$ from fruit extract of Ananas Comosus was made of high purity zinc nanoparticles. According to S. S. Kumar et al. (2013), the energy dispersive spectra of the samples obtained from the FESEM-EDX analysis showed that the sample prepared by the above route has pure $\mathrm{ZnO}$ phases which was similar to the results obtained in the present study. Then, the elemental composition of ZnO-NPs sample was summarized in Table 1. The presence of oxygen and zinc elements in the nanoparticles was confirmed by the EDX results. The spectrum in Fig. 3 showed that $\mathrm{ZnO}-\mathrm{NPs}$ were consisted of $\mathrm{O}$ and $\mathrm{Zn}$ elements with the percentages of $31.62 \%$ and $68.38 \%$ that given in Table 1 respectively, thus proving that the produced $\mathrm{ZnO}$-NPs were in highest 
purified form and also were in agreement with the earlier studies (Raj and Jayalakshmy 2015). It was shown that the significant peaks obtained for the $\mathrm{ZnO}$ sample were similar to the peaks obtained in previous work by Raj and Jayalakshmy (2015) when they succeed in synthesizing $\mathrm{ZnO}$ from the root extract of Zingiber Officinale (Raj and Jayalakshmy 2015).

\section{UV-Vis absorption analysis}

UV-Vis absorption spectrum analysis in this study was used to confirm the ZnO-NPs formation (B. Kumar et al., 2014). Concurrently, it was possible to monitor the stability of the biosynthesized nanoparticles (Zhang et al., 2016). Fig. 5 presents the absorption peak of the $\mathrm{ZnO}-\mathrm{NPs}$ around $370 \mathrm{~nm}$ which was in the range of characteristic peak of $\mathrm{ZnO}-\mathrm{NPs}$ from previous study (Khorsand Zak et al. 2011). It was specified that the ZnO-NPs exhibited exciton absorption at $370 \mathrm{~nm}$, owing to their large exciton binding energy at room temperature. Absorption in the wavelength of $370 \mathrm{~nm}$ was further confirmed that the absorption spectrum was slightly blue shifted, pertaining to the bulk value $(377 \mathrm{~nm})$ of $\mathrm{ZnO}$ NPs. The shifted line in the absorption edge was due to the quantum confinement effect between the individual nanoparticles (Elumalai et al., 2015). According to Gupta et al. (2015), the reducing size of the nanoparticle generally could be recognized with the absorption edge that systematically shifted to the lower wavelength or higher energy (Gupta et al. 2015).

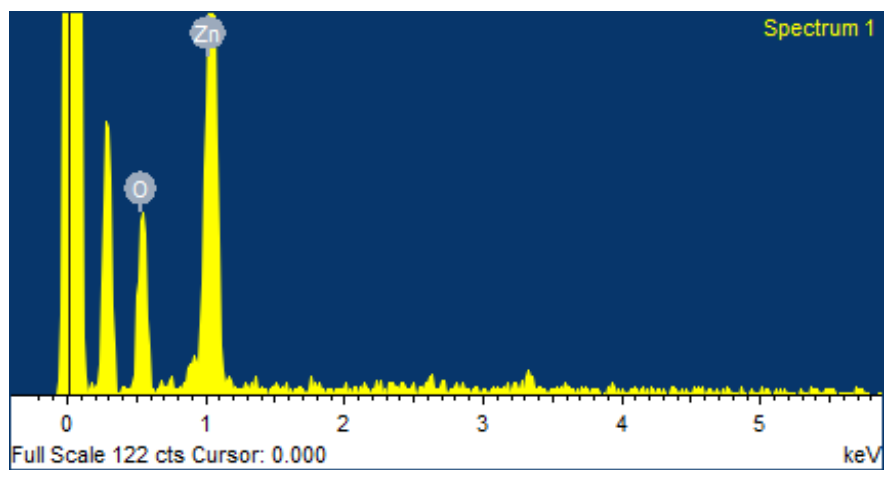

Fig.4 EDX spectrum of biosynthesized ZnO-NPs.

Table 1 Elemental analysis by EDX for ZnO-NPs.

\begin{tabular}{ccc}
\hline Component & Weight\% & Atomic\% \\
\hline $\mathrm{O}$ & 31.62 & 65.39 \\
$\mathrm{Zn}$ & 68.38 & 34.61 \\
\hline
\end{tabular}

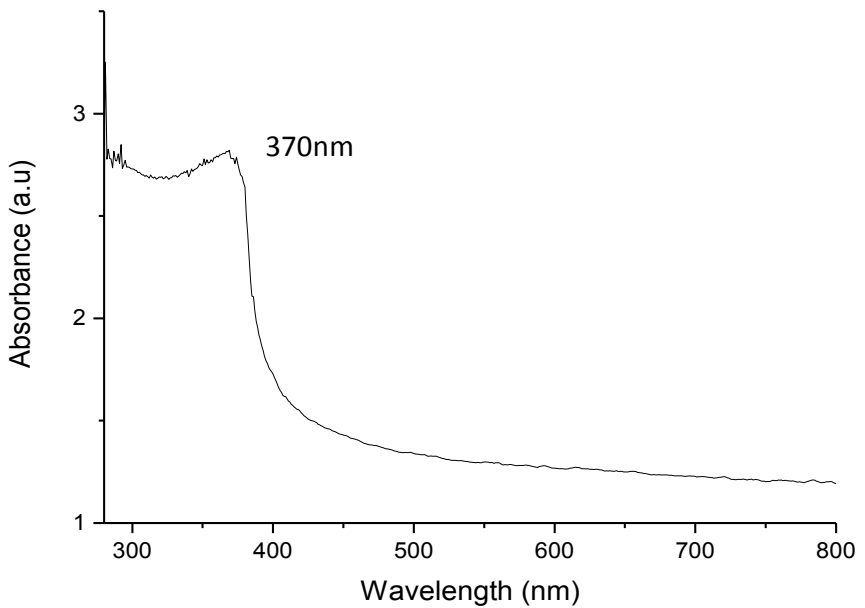

Fig. 5. UV-Vis absorbance of ZnO-NPs.

\section{Evaluation of antibacterial activity}

The antibacterial properties of $\mathrm{ZnO}-\mathrm{NPs}$ have been analyzed by agar diffusion methods and the results were shown in Fig. 6. The antibacterial activity of $\mathrm{ZnO}-\mathrm{NPs}$ against bacterial strains of $E$. coli ATCC 25922 was measured as area of inhibition zone. The inhibition zone could be clearly observed in the biosynthesized ZnO-NPs and commercial $\mathrm{ZnO}-\mathrm{NPs}$ which proved the antibacterial properties of both nanoparticles. In addition, the zone of inhibition produced by the biosynthesized $\mathrm{ZnO}-\mathrm{NPs}$ was larger than the commercial $\mathrm{ZnO}-\mathrm{NPs}$ which was in correlation to the previous work done by Gunalan, Sivaraj, and Rajendran (2012) which reported that the inhibitory effect of the green synthesized nanoparticles was bigger than chemically synthesized nanoparticles. Table 2 presents the inhibition area of the samples $\left(\mathrm{mm}^{2}\right)$. The inhibition areas of the commercial $\mathrm{ZnO}$, biosynthesized $\mathrm{ZnO}^{\mathrm{a}}$ and biosynthesized $\mathrm{ZnO}^{\mathrm{b}}$ were $18.76 \mathrm{~mm}^{2}$, $24.704 \mathrm{~mm}^{2}$ and $51.428 \mathrm{~mm}^{2}$, respectively. Other than that, the percentage differences of the biosynthesized $\mathrm{ZnO}^{\mathrm{a}}$ and biosynthesized $\mathrm{ZnO}^{\mathrm{b}}$ were $31.5 \%$ and $173.84 \%$, respectively in comparison to commercial $\mathrm{ZnO}$. It was proved that the biosynthesized $\mathrm{ZnO}$ was superior in terms of antibacterial properties as opposed to ZnO-NPs. Also, it was shown in the earlier study by Wahab et al., (2010) that by increasing the concentration of ZnO-NPs in wells and discs, the growth inhibition has also been increased (Wahab et al., 2010). In addition to that, the size of inhibition zone was affected by various factors such as the type of bacteria, the size, and the concentrations of ZnO-NPs (Zarrindokht Emami-Karvani, 2012) 


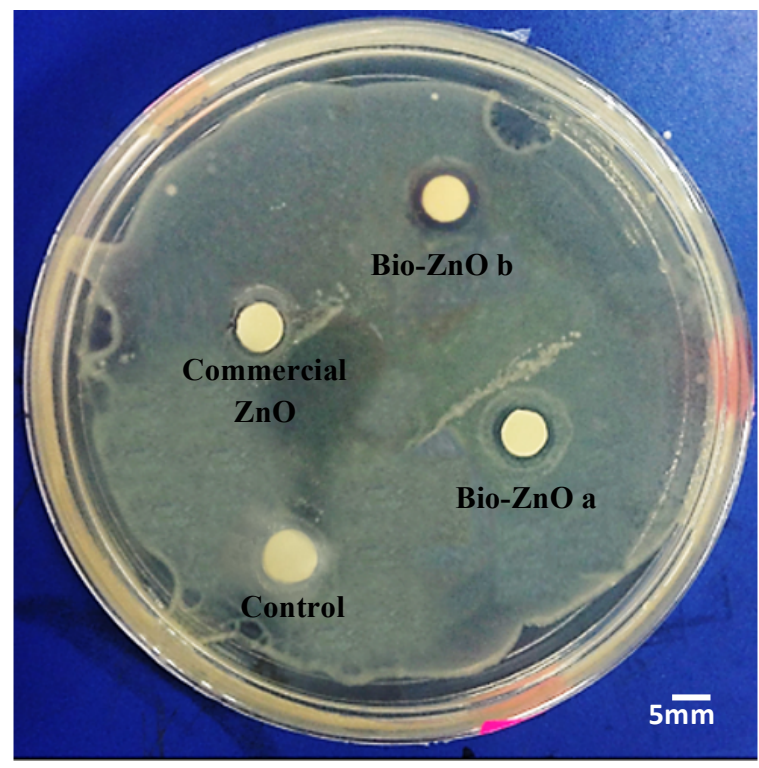

Fig. 6. Antibacterial activity of ZnO-NPs.

Table 2. Inhibition area of ZnO-NPs.

\begin{tabular}{cccc}
\hline Component & $\begin{array}{c}\text { Inhibition area } \\
\left(\mathbf{m m}^{2}\right)\end{array}$ & & $\begin{array}{c}\text { \% difference with } \\
\text { commercial }\end{array}$ \\
\hline Control & 0 & \\
Commercial $\mathrm{ZnO}$ & 18.78 & 31.5 \\
Biosynthesized $\mathrm{ZnO}^{\mathrm{a}}$ & 24.704 & 173.84 \\
Biosynthesis $\mathrm{ZnO}^{\mathrm{b}}$ & 51.428 & \\
\hline
\end{tabular}

\section{CONCLUSION}

The rapid biological synthesis of ZnO-NPs using a fruits extract of Ananas Comosus as reducing agent was successfully conducted and the results proved that the biosynthesized $\mathrm{ZnO}$ was simple, ecofriendly, cost effective and offered pertinent route for synthesis of nanoparticles. The size of synthesized nanoparticles $\mathrm{ZnO}$ was in the range of $30-57 \mathrm{~nm}$. The morphology of the $\mathrm{ZnO}-\mathrm{NPs}$ was characterized by using FESEM. EDX analysis revealed that the purity of $\mathrm{ZnO}$ was in line with the XRD result. The absorbance obtained from the UV-Vis spectrum analysis also showed the absorption peak of the $\mathrm{ZnO}-\mathrm{NPs}$ is at around $370 \mathrm{~nm}$. It was proven in this study that the biosynthesized $\mathrm{ZnO}$-NPs were acted as an effective antibacterial agent against common pathogenic microorganisms. It was also believed that the use of plant extracts in the synthetic procedure resulted in enhanced antibacterial and antioxidant properties of $\mathrm{ZnO}$ NPs. Therefore, it could be concluded that the green synthesis of ZnO-NPs using Ananas Comosus fruits extract has a tremendous potential as an alternative to chemical methods.

\section{ACKNOWLEDGEMENT}

This work was financially supported by the Universiti Tun Hussein Onn Malaysia under the Transdisciplinary Research Grant Scheme, TRGS Vot T002 and Ministry of Higher Education Malaysia.

\section{REFERENCES}

Applerot, Wiberg, E, Holleman A. F., 2009. Inorganic Chemistry. Elsevier 22: 24-34. Brayner, Basu, 2006. Elsevier 1225-1229.

Arora, S. K., Devi, A., Jaswal, V. S., Singh, J., Kinger, M., \& Gupta, V. D. (2014). Synthesis and characterization of $\mathrm{ZnO}$ nanoparticles. Oriental Journal of Chemistry 30(4): 1671-1679.

Azizi, S., Ahmad, M. B., Namvar, F., \& Mohamad, R. (2014). Green biosynthesis and characterization of zinc oxide nanoparticles using brown marine macroalga Sargassum muticum aqueous extract. Materials Letters 116: 275-277.

Balta, Stefan et al. 2012. A new outlook on membrane enhancement with nanoparticles: The alternative of $\mathrm{ZnO}$. Journal of Membrane Science 389: 155-61.

Chen, X., Wu, Z., Liu, D., and Gao, Z. 2017. Preparation of ZnO photocatalyst for the efficient and rapid photocatalytic degradation of azo dyes. Nanoscale Research Letters 12(1): 143.

Dobrucka, Renata, and Jolanta Długaszewska. 2015. Biosynthesis and antibacterial activity of $\mathrm{ZnO}$ nanoparticles using trifolium pratense flower extract. Saudi Journal of Biological Sciences 23: 517-23.

Elumalai, K., \& Velmurugan, S. (2015). Green synthesis, characterization and antimicrobial activities of zinc oxide nanoparticles from the leaf extract of Azadirachta indica (L.). Applied Surface Science 345: 329-336.

Emami-Karvani, Z., Chehrazi, P. 2012. Antibacterial activity of $\mathrm{ZnO}$ nanoparticle on gram-positive and gram-negative bacteria. African Journal of Microbiology Research, 5(12): 1368-1373.

Galstyan, V., Comini, E., Baratto, C., Faglia, G., Sberveglieri, G. 2015. Nanostructured $\mathrm{ZnO}$ chemical gas sensors. Ceramics International 41(10 Part B): 14239-14244.

Giancaterini, L., Cantalini, C., Cittadini, M., Sturaro, M., Guglielmi, M., Martucci, A., Resmini, A., Anselmi-Tamburini, U. 2014. Au and Pt nanoparticles effects on the optical and electrical gas sensing properties of sol-gel based $\mathrm{ZnO}$ thin film sensors. IEEE Sensors Journal 15(2): 10681076 .

Gunalan, S., Sivaraj, R., \& Rajendran, V. (2012). Green synthesized ZnO nanoparticles against bacterial and fungal pathogens. Progress in Natural Science: Materials International 22(6): 693-700.

Gupta, A., Srivastava, P., Bahadur, L., Amalnerkar, D. P., Chauhan, R. 2015. Comparison of physical and electrochemical properties of $\mathrm{ZnO}$ prepared via different surfactant-assisted precipitation routes. Applied Nanoscience 5(7): 787-794.

Jeeva Lakshmi, V., Sharath, R., Chandraprabha, M. N., Neelufar, E., Abhishikta, H., Malyasree, P. 2012. Synthesis, characterization and evaluation of antimicrobial activity of zinc oxide nanoparticles. Journal of Biochemical Technology 3(5): S151-S154.

Karimi-Maleh, H., Tahernejad-Javazmi, F., Gupta, K. V., Ahmar, H., Asadi, M. H. 2014. A novel biosensor for liquid phase determination of glutathione and amoxicillin in biological and pharmaceutical samples using a $\mathrm{ZnO} / \mathrm{CNTs}$ nanocomposite/catechol derivative modified electrode. Journal of Molecular Liquids 196: 258-263.

Karunakaran, C., Rajeswari, V., \& Gomathisankar, P. (2011). Materials science in semiconductor processing enhanced photocatalytic and antibacterial activities of sol-gel synthesized $\mathrm{ZnO}$ and $\mathrm{Ag}-\mathrm{ZnO}$. Materials Science in Semiconductor Processing 14(2): 133-138.

Khorsand Zak, A., R. Razali, W. H. Abd Majid, and Majid Darroudi. 2011. Synthesis and characterization of a narrow size distribution of zinc oxide nanoparticles. International Journal of Nanomedicine 6(1): 1399-1403.

Könenkamp, R., Dloczik, L., Ernst, K., and Olesch, C. 2002. Nano-structures for solar cells with extremely thin absorbers. Physica E: Low-dimensional Systems and Nanostructures 14(1-2): 219-23.

Kumar, B., Smita, K., Cumbal, L., and Debut, A. 2014. Green approach for fabrication and applications of zinc oxide nanoparticles. Bioinorganic Chemistry and Applications 2014: 523869.

Kumar, S. S., Venkateswarlu, P., Rao, V. R., and Rao, N. G. 2013. Synthesis, characterization and optical properties of zinc oxide nanoparticles. International Nano Letters 3(1): 30.

Lu, Pei Jia P.-J., Huang, S.-C., Chen, Y.-P., Chiueh, L.-C., Shih, D. Y.-C. et al. 2015. Analysis of titanium dioxide and zinc oxide nanoparticles in cosmetics. Journal of Food and Drug Analysis 23(3): 587-594.

Lu, Y.-J., Shi, Z.-F., Shan, C.-X., and Shen, D.-Z. 2017. ZnO-based deepultraviolet light-emitting devices. Chinese Physics B 26(4): 47703.

Prasad, N. S. T. N. V. K. V, \& Krishna, T. G. (2016). Synthesis, characterization, and evaluation of the antimicrobial efficacy of Boswellia ovalifoliolata stem bark-extract-mediated zinc oxide nanoparticles. Applied Nanoscience 6(4): 581-590.

Raj, L. F. A., and Jayalakshmy E. 2015. Biosynthesis and characterization of zinc oxide nanoparticles using root extract of Zingiber officinale. Oriental Journal of Chemistry 31(1): 51-56.

Shrikant, R. Kulkarni, D. B., Borse, A. D., Agarwal, S. P., Saptale. 2011. Green synthesis of Ag nanoparticles using vitamin C (ascorbic acid) in a batch process. IEEE Sensors Journal 3: 88-90.

Stan, M., Popa, A., Toloman, D., Dan, T. S., \& Vodnar, C. (2016). Antibacterial and antioxidant activities of $\mathrm{ZnO}$ nanoparticles synthesized using extracts of Allium sativum, Rosmarinus officinalis and Ocimum basilicum. Acta Metallurgica Sinica (English Letters) 29(3): 228-236.

Sutradhar, P., and Saha, M. 2017. Green synthesis of zinc oxide nanoparticles using tomato (Lycopersicon Esculentum) extract and its photovoltaic application. Journal of Experimental Nanoscience 11(5): 314-27. 
Vittal, R., Ho, K. -C. 2017. Zinc oxide based dye-sensitized solar cells: A review. Renewable and Sustainable Energy Reviews 70: 920-935.

Wahab, R., Kim, Y. S., Mishra, A., Yun, S. Il, \& Shin, H. S. (2010). Formation of $\mathrm{ZnO}$ micro-flowers prepared via solution process and their antibacterial activity. Nanoscale Research Letters 5(10): 1675-1681.

Zhang, X.-F., Liu, Z.-G., Shen, W., and Gurunathan, S. 2016. Silver nanoparticles: synthesis, characterization, properties, applications, and therapeutic approaches. International Journal of Molecular Sciences 17(9): E1534

Zheng, Y., Fu, L., Han, F., Wang, A., Cai, W., Yu, J., ... Peng, F. (2015). Green biosynthesis and characterization of zinc oxide nanoparticles using Corymbia citriodora leaf extract and their photocatalytic activity. Green Chemistry Letters and Reviews, 8(2): 59-63. 